DOI: 10.46340/eppd.2020.7.4.10

\author{
Olha Volianiuk, PhD in Political Science \\ ORCID ID: https://orcid.org/0000-0002-1606-7416 \\ National Pedagogical Dragomanov University, Ukraine
}

\title{
APPLIED POLITICAL RESEARCH: TOWARDS REALITY
}

\author{
Ольга Волянюк, к. політ. н. \\ Національний педагогічний університет імені М.П. Драгоманова, Україна
}

\section{ПРИКЛАДНІ ПОЛІТИЧНІ ДОСЛІДЖЕННЯ: НАЗУСТРІЧ РЕАЛЬНОСТІ}

The tendencies of development of applied political science under the influence of political reality are analyzed. They are defined on three levels: problem statement; choice of methods; preparation of recommendations. Some conclusions are made on the basis of monitoring of political science publications, observations on the analytical centers: 1) applied political science is enriched with new topics close to the realities of specific political communities; 2) policy research methods become more complicated with the development of the information society, become customer-oriented; 3 ) social distrust and interdependence obliges to develop various forms of cooperation between all stakeholders, interested in applied political research.

Keywords: action-oriented political research, applied political science, political reality, research methods, think tank.

Розвивати політологію в прикладних дослідженнях у наш час означає знаходити практичне втілення політичним знанням, протистояти псевдоекспертизі політичних явищ і процесів, дбати про споживача політичних теорій, зміцнювати / відновлювати довіру до соціальних наук загалом i політичних зокрема. Прикладне політичне дослідження відрізняється своєю максимальною чутливістю до реальності. Його потребують різні галузі суспільного життя; відповідними напрацюваннями можуть користуватися урядові структури, представницькі органи влади, політичні партії, громадські об’єднання, адвокасі-групи, медіа, професійні спілки, промислові компанії тощо.

У цій статті ставимо за мету розкрити основні тенденції розвитку прикладної політології, сучасні тренди політичної аналітики, які постають у відповідь на актуальні суспільні запити та водночас самі до певної міри визначають політичну реальність, ії порядок денний і перспективу.

Методологія дослідження базується на принципах об'єктивності, системності, плюралізму. Відстежити основні тенденції розвитку прикладної політології допоміг моніторинг статей, що публікуються у провідних виданнях з політичних наук. Осмислити зміни в методиках і презентації результатів прикладних політичних досліджень дозволили також системні спостереження, зокрема за діяльністю наукових, освітніх, аналітичних центрів України.

Зауважимо, що прикладне політичне дослідження передбачає здатність: 1) розпізнавати i сприймати актуальні завдання порядку денного політики (самостійно їх вирізняти i/чи оперативно відповідати на суспільні, партійні, урядові чи інші тематичні запити); 2) володіти методиками аналізу актуальних політичних проблем та їх вирішення, інструментами науково-пошукової роботи, техніками обробки даних в політичній науці; 3) пропонувати ефективні й альтернативні шляхи вирішення завдань політичного ринку (напрацьовувати проєкти нормативних документів, виборчі стратегії, сценарії політичного розвитку, прогнози й оцінки політичних ризиків, ситуаційні та стратегічні угоди; надавати конкретні політичні послуги, інформаційний супровід, контент-плани, івент-календарі тощо).

У наш час на кожному зі згаданих рівнів прикладної політології спостерігаємо урізноманітнення та зростання чисельності наукових напрацювань. Якщо оглянути пул текстів, накопичених за останні роки у цій галузі, можна помітити розширення предметного поля. Тобто на рівні ідентифікації та констатації актуальних завдань політики виявляються теми, які раніше перебували поза увагою політичних аналітиків або ж вивчалися переважно зі теоретичних позицій. 
Конкретизувати цю думку допоможуть приклади, зокрема наукові статті, які викликають особливий інтерес читачів.

Наприклад, кращі напрацювання з різних куточків світу презентує журнал Міжнародної асоціації політологів «The International Political Science Review», що покликаний сприяти політичним дослідженням із позиції різних підходів. Серед найцитованіших статей останніх 3-х років чимало академічного контенту носить прикладний характер. Зокрема розглядаються такі проблеми: кросрегіональне порівняння популізму та його прояви в офіційній політиці; вплив інвалідності на політичну участь; підстави для радикалізації груп однодумців; залежність представництва інтересів виборчих округів від їх масштабів; організаційні детермінанти електоральної інтегрованості; вплив релігійності на політичну упередженість громадян; концентрація та політичне представництво іммігрантів; кар'єрні амбіції та інтеграція в локальні соціальні мережі як фактори політичної активності тощо.

Щодо актуалізації у науці реальних проблем політики нашу увагу привертає також спеціалізований «Journal of Experimental Political Science» ${ }^{2}$. Останні три роки топові позиції у ньому займають дослідження, наприклад, із таких проблем: чутливість політичних еліт і посадових осіб, їх реагування на дискримінацію; наслідки протидії «фейковим» новинам; поведінка респондентів в Інтернет-опитуваннях; вплив погоди на явку виборців; зв'язок між застосуванням насильства та прихильністю людей до сильної держави; вплив квот на середні показники гендерної упередженості громадян; вплив спортивних змагань на громадську думку; ставлення громадян до прямих іноземних інвестицій; вплив на виборців особистісної та вокальної компетентності кандидатів тощо. Подібні проблеми розглядаються також на сторінках міжнародних видань із прикладної політології«Electoral Studies», «Journal of Political Marketing», «Public Choice», «Journal of Information Technology $\&$ Politics», «Political Analysis» та ін. Чимало тем перегукуються.

В Україні окреслити пріоритетні напрямки розвитку прикладної політології складніше. Це пов'язано і з неоднозначною радянською спадщиною, і з гібридною зовнішньою агресією, політичною ангажованістю, частковою залежністю науки та політичної аналітики. Наприклад, у 1990-х рр. серед найцитованіших згадувалась книга «Нариси практичної політології» (Київ, 1991 р.) Д. Видріна, але вже в наш час автор дискредитував репутацію професійного політолога, опублікувавши «путінознавчу» роботу ${ }^{3}$ в анексованому Криму. В Україні політична наука нарощувала переважно теоретичний потенціал. Поступово у вжиток запроваджувалися поняття «електоральна» / «аналітична» / «воєнна» / «порівняльна» політологія. Над окремими зі цих напрямів працювали П. Демчук, В. Кривошеїн, Є. Перегуда, А. Пойченко, В. Ребкало та ін. Наприкінці 2000-х рр. предметне поле, загальну логіку, структуру прикладної політології окреслив колектив авторів (О. Бойко, В. Горбатенко, Г. Зеленько, В. Корнієнко, В. Смолянюк та ін.) у підручнику «Прикладна політологія» (К., 2008 р.). У наш час досі немає єдиного спеціалізованого періодичного видання, за яким можна було би системно відстежувати тенденції розвитку виключно прикладних політичних досліджень в Україні, тих наукових розвідок, що пов'язанні з політичними реаліями, практикою політичного управління, мають обмежені просторово-часові рамки. Подібні напрацювання існують та безумовно заслуговують окремого дослідження. Вони продовжують публікуватися осібно, переважно у фахових виданнях з політичних наук, яких станом на липень 2020 р. налічувалося $16^{4}$, але перелік яких часто змінюється.

У центрі уваги прикладної політології не лише усереднені показники чи загальні статистичні звіти, але й окремі випадки, (не)типові явища в політиці. Подібні дослідницькі рішення потребують і точніших інструментів аналітики. Не випадково, огляд найновіших західних видань 3 прикладної політології орієнтує саме на метод дослідження (другу позицію у нашій статті). Наприклад, британський професор політичних наук П. Джон нещодавно опублікував збірку практичних вказівок

\footnotetext{
${ }^{1}$ The International Political Science Review: Most cited articles published in this journal in the last 3 years. SAGE Publishing. <https://journals.sagepub.com/action/showMostCitedArticles?journalCode=ipsa> (2020, липень, 03).

${ }^{2}$ Journal of Experimental Political Science: most cited articles in the last three years. Cambridge Core. $<$ https://www.cambridge.org/core/journals/journal-of-experimental-political-science/most-cited $>$ (2020, липень, 03).

${ }_{3}^{3}$ Воротинський, I. Реінкарнація радника, або Навіщо Видрін написав книгу для Путіна. Укрінформ. $<$ https://www.ukrinform.ua/rubric-world/2860112-reinkarnacia-radnika-abo-naviso-vidrin-napisav-knigu-dla-putina.html> . (2020, січень, 21).

${ }^{4}$ Реєстр наукових фахових видань України. ДНУ "Украӥнський інститут науково-технічної експертизи та інформаиіï". <http://resources.ukrintei.ua/refer/search> (2020, липень, 20).
} 
на основі результатів багаторічних польових експериментів. Автор вчить проектувати, організовувати, аналізувати експерименти для політичної сфери та управляти цими «рандомізованими контрольованими випробуваннями». Це досвід прикладного дослідження таких проблем як голосування, політична участь, вплив (nudging) на громадян та підштовхування країн, що розвиваються. Вже в назві книги професор акцентує на взаємопов'язаності наукового пошуку та практичної політики, вагомості партнерства між ними. Ані «зміни у реальному світі», які продукують розробники політики й ті, хто приймають політичні рішення, ані «умови / контексти реального світу», які складають особливий інтерес для політологів, неможливо осягнути без дієвої співпраці між цими суб'єктами ${ }^{1}$.

Безумовно метод експерименту не новий для соціальних наук, однак у наш час він дозволяє краще зрозуміти політичну реальність, причинно-наслідкові взаємозв'язки. Загалом кожен такий метод потребує чутливості, усвідомлення можливостей та обмежень, базових кроків з його планування й прихованих загроз імплементації, уважного підбору окремих випадків тощо. Дискусійною видається й проблема етичного характеру в організації подібного аналізу соціальнополітичних процесів, де вагомими є людський фактор, суб'єктивізм, приватність, безпека тощо.

Лабораторні / оглядові / польові експерименти важливі та не єдині методи сучасного політичного дослідження. Огляд всього їх різноманіття, власне, і не складає завдання цієї статті. Тут вкажемо лише на окремі тренди, зокрема важливі для сучасного політичного життя реалії цифрового суспільства. Адже у якості методу прикладна політична аналітика також розвивається на базі сучасних комп'ютерних технологій, залучаючи здобутки економічної науки, інженерії, обчислювальної соціології. Корисною методологією для розуміння політичних процесів, прийняття політичних рішень виявилися, наприклад, агентне моделювання (з англ. agent-based model, ABM), a також системна динаміка (з англ. System Dynamics, SD). Цей науковий підхід / спосіб дослідження складних і динамічних взаємозв'язків всередині систем використовується для моделювання їх поведінки через процеси зворотних зв'язків, різних взаємодій, часових потоків, елементів, взаємозалежностей ${ }^{2}$. Сучасні прикладні політичні дослідження, побудовані за такою методологією, ці елементи, зазвичай, візуалізують у макетах, чітких схемах, що вміщують найважливішу інформацію про систему, їі стан, стійкість, рівновагу. Через ABM та SD можна аналізувати складні системи політики - діяльність окремих органів влади чи їх взаємозв'язки, урядову політику в конкретній сфері, партійну організацію, поведінку виборців тощо.

На прикладі SD спостерігаємо, як політичні дослідження поступово відходять від умовних припущень, але при цьому намагаються бути зрозумілішими для широкого загалу споживачів політичних продуктів. На основі математичних моделей сьогодні пропонуються послідовні структури вирішення конкретних проблем, різні їх бачення серед зацікавлених сторін, реальні важелі впливу на політику. Такі інструменти достатньо інтерактивні, тобто презентуючи їх замовнику, можна також передбачити можливість апробації ним самим відповідної моделі, експериментального вводу окремих параметрів, залежних змінних, а відтак й усвідомлення ним власної ролі та усіх складнощів у системі політичних взаємозв'язків. Це ще й потужний просвітницький інструмент, коли за допомогою прикладного дослідження широке коло початківців отримує доступ до результатів експертного знання. Він зокрема корисний для роз'яснення загроз і перспектив екологічної, молодіжної, енергетичної політики тощо.

Нарешті на умовному третьому рівні прикладного політичного дослідження - розробка шляхів вирішення завдань політичного ринку- найціннішою видається ефективність, інституційна спроможність, досяжність, реалістичність, конкурентоспроможність пропонованих проєктів / програм / стратегій. Йдеться про якість аналітичного продукту, кінцевого результату прикладного дослідження. 3 розвитком демократії вимоги до консалтингових послуг, адвокації чи експертних звітів політологів зростають. Сьогодні це не лише розробка рішення, але і його грамотне позиціонування, проєктно-орієнтоване планування, робота зі цільовою аудиторією тощо.

На ринку України спостерігаємо зростання інтересу до прикладної політології та іï напрацювань. Наприклад, на це вказує журналістська спільнота, зіткнувшись ще й з проблемами перенасичення медіа «псевдополітологами», нестачею кваліфікованих фахівців із конкретних

\footnotetext{
${ }^{1}$ John, P. (2017). Field Experiments in Political Science and Public Policy. New York: Routledge, 9. $<$ doi:https://doi.org/10.4324/9781315773025>.

2 Див. напр.: Ford, D.N. (2019). A system dynamics glossary. Syst. Dyn. Rev., 35, 4, 369-379. <doi:10.1002/sdr.1641>; Fernández-Márquez, C.M., Vázquez, F.J., Medina, L.F. (2019). Imperfect Knowledge and Stable Governance in Democracies: An Agent-Based Model. Political Research Quarterly. <doi: https://doi.org/10.1177/1065912919834655>.
} 
політичних питань міжнародного / національного / локального порядку денного, поширеним страхом публічності. Окремі фінансово-промислові групи України та зовнішньополітичні актори обрали досить агресивну модель позиціонування власних інтересів у суспільстві- зокрема i за посередництва ангажованих аналітиків і центрів. Зручна для цих впливових суб'єктів української політики структура власності на ЗМІ відображається і на індексах цитування політологів у них, досить умовних рейтингах медіа-впізнаваності політичних експертів. Такі рейтинги регулярно складають все ті ж, не завжди прозорі у своїй діяльності «аналітично-консалтингові об’єднання» ${ }^{1}$.

У відповідь журналісти, об'єднавшись у професійні спільноти, збирають поради щодо грамотного пошуку коментаторів політичних тем², періодично викривають ангажованих політичних експертів, тих, що фігурують переважно у передвиборчих публікаціях тощо 3 . Політична публіцистика містить елементи прикладного політичного дослідження, тому журналістські розслідування потребують залучення незалежних оцінок, прозорих даних, фахової експертизи. I навпаки, незалежні наукові ініціативи потребують медіа підтримки.

При підготовці практичних рекомендацій важливо не перетнути межу реалістичностіштучності, коли проблеми аналізу видаються надуманими, методики їх дослідження неадекватними, а результати - позбавлені практичної цінності та об'єктивності. Відмітимо, що 3 подібними труднощами зіткнулися і західні політологи. На прикладі двох публікацій 2006 p. ${ }^{4}$ та $2020 \mathrm{p}^{5}$ можемо спостерігати, як вже багато років часто одні й ті ж вчені працюють над цією проблематикою: від загальних міркувань про практичне значення політичної науки (зокрема причини нестачі плідного зв'язку між науковцями, які прагнуть зрозуміти політичні процеси, і тими, хто має аналогічне завдання у практичній політиці) до пошуку конкретних стратегій, які посилювали б соціальний вплив політичних досліджень. Головна увага зосереджена на відмові від інструменталізації політології, зміцненні дослідницьких мереж, посиленні комунікативної методології, налагодженні зворотного зв'язку.

Цікавою в цьому зв'язку є й діяльність аналітичних центрів - середовища професійної самореалізації багатьох політологів, серед послуг яких прикладні політичні дослідження. Навколо напрацювань таких осередків чимало дискусій, а міжнародна практика поступово прийшла до формування глобальних мереж і навіть певних інструментів, які дозволяли б серед експертноаналітичних організацій виокремлювати різні: за спрямованістю, ефективністю, незалежністю та іншими критеріями ${ }^{6}$. Результати роботи «фабрик думок» залежать від динаміки громадянського суспільства, політичної системи загалом, тож в Україні спостерігаємо суперечливі тенденції щодо їх впливу на політичні реалії. Для підтвердження цієї думки наведемо декілька окремих прикладів.

Серед найпотужніших (за версією згаданого рейтингу Дж. МакГанна) think tanks не лише в Україні, але й світі - Центр Разумкова, який регулярно публікує результати роботи власної соціологічної служби, прогнози політичного розвитку, практичні рекомендації вирішення суспільнополітичних проблем. Підкреслимо, що ці матеріали переважно презентуються зі залученням широкого кола експертів, зацікавлених сторін, державних суб'єктів і зарубіжних агентів, що посилює їх значимість. Наприклад, через попереднє експертне опитування, згодом у професійних дискусіях представлено важливі для сучасної політики у галузі освіти і науки інформаційно-аналітичні матеріали «Політична освіта в Україні: стан і проблеми розвитку» 7.

\footnotetext{
${ }^{1}$ Рейтинг медиапопулярности украинских политических экспертов. Украинский институт политики. $<\mathrm{http}$ ://rating.uiamp.org.ua/politicheskie-eksperty-i-kommentatory-v-smi-itogi-iyunya-0> (2020, липень, 03). ${ }^{2}$ Герасим, Г. Як шукати коментаторів політичних тем. MediaLab Online.

$<\mathrm{https://medialab.online/news/politology/>} \mathrm{(2019,} \mathrm{лютий,} \mathrm{12).}$

${ }^{3}$ Див. напр. Приховані піарники. Тексти. <https://texty.org.ua/d/socio/\#people > (2020, липень, 03).

${ }^{4}$ Donovan, C., Larkin, P. (2006). The Problem of Political Science and Practical Politics. Politics, 26(1), 11-17. $<$ doi:https://doi.org/10.1111/j.1467-9256.2006.00246.x>.

${ }^{5}$ Aiello, E., Donovan, C., Duque, E., Fabrizio, S., Flecha, R. Holm, P., Molina, S., Oliver, E, Reale, E. (2020). Effective strategies that enhance the social impact of social sciences and humanities research. Evidence \& Policy, 1-16. $<$ doi: https://doi.org/10.1332/174426420X15834126054137>.

${ }^{6}$ Див. напр. McGann, James G. 2019 Global Go To Think Tank Index Report. TTCSP Global Go To Think Tank

Index Reports, 17. <https://repository.upenn.edu/think_tanks/17/> (2020, січень, 27).

${ }^{7}$ Круглий стіл «Політична освіта в Україні: сучасний стан і перспективи удосконалення». Центр Разумкова. $<$ http://razumkov.org.ua/novyny/kruglyi-stil-politychna-osvita-v-ukraini-suchasnyi-stan-i-perspektyvy-udoskonalennia> (2019, грудень, 18).
} 
Аналітичні центри роблять свій внесок і в зміцнення національної безпеки. Використовуючи техніки та методики OSINT, професійні об'єднання журналістів і волонтерів (Bellingcat, InformNapalm та ін.) працюють із великими масивами відкритих в онлайн-просторі джерел соціальними мережами, блогами, мобільними додатками, Google-інструментами тощо - на основі яких аналізують цінну розвідувальну інформацію. Мережева розвідка, наприклад, викрила роль приватних військових компаній у політичних маніпуляціях та гібридній агресії, напрацювала способи протидії гібридним арміям ${ }^{1}$.

3 розширенням доступу до суспільно важливої інформації в Україні започатковано чимало ініціатив, які на основі цього масиву готують важливі узагальнення та звіти. Наприклад, завдяки зусиллям одного із кращих у Центральній та Східній Європі think tanks (за даними того ж рейтингу) Міжнародного центру перспективних досліджень - доступна комплексна оцінка прозорості українських державних підприємств та органів місцевого самоврядування ${ }^{2}$. Цим продуктом можуть вільно користуватися у своїй діяльності інвестори, дослідники, інші зацікавленні суб'єкти політики. Зауважимо, що такі аналітичні звіти співзвучні зростаючому числу наукових досліджень політологів, які вже багато років працюють над проблематикою місцевого самоврядування в Україні, а сьогодні розробляють конкретні механізми локальної демократії․

Окремої уваги заслуговує діяльність центрів, що мають університетську афілітацію. Серед них і деякі студентські об'єднання ${ }^{4}$, на прикладі яких можна спостерігати за спробами трансформації контенту й результатів грунтовної політичної аналітики удоступні формати, увиразнення адвокаційної та медійної складових прикладного дослідження. Ці не завжди стабільні, часто неформалізовані об'єднання з різних міст України рідко проводять глибинні дослідження політики, однак популяризують потужні дослідницькі напрацюванням політологів, поширюють відповідні знання, здобутки, ідеї.

Узагальнюючи результати нашого дослідження, відмітимо деякі особливості прикладної політології останніх років за трьома напрямками. 1) Тематично ії предметне поле розширюється та поглиблюється у case-studies. Від загальних, універсальних проблем міжнародних відносин, політичних систем, поведінки виборців тощо науковці виходять назустріч політичній реальності, до вивчення окремих іiї вимірів, наприклад, безпеки в умовах популізму й дезінформації, якості й доступності політичного сервісу, електоральних емоцій тощо. 2) Поступове усунення розриву між політичними дослідженнями та сучасними реаліями помітне й у виборі методів. Комп'ютерне моделювання, робота з великим даними чи експерименти зі соціально-політичних питань часто організовані таким чином, щоб їх ефект і значимість могли апробувати безпосередні учасники політичних відносин. 3) Особливості позиціонування результатів прикладного політичного дослідження на освітньому, науковому, політичному ринках часто визначають загальний успіх дослідницького проєкту. У цьому зв'язку велику роль відіграє подальше утвердження принципів об'єктивності, незалежності, прозорості, співробітництва. Важливо на їх основі розвивати міцні та продуктивні зв'язки між різними поколіннями політичних аналітиків, освітян, дослідників політичних проблем, урядовцями тощо.

Стосовно рекомендацій варто зазначити, що позиції прикладних політичних досліджень могли б суттєво посилити: вузько тематичні конференції, фахові періодичні видання з окремих напрямів прикладної політології, міждисциплінарні проєкти щодо реальних суспільно-політичних проблем.

\footnotetext{
1 Звіт про роль російських приватних армій у збройних конфліктах. InformNapalm: International Volunteer Community. <https://informnapalm.rocks/pmc-rush-ua> (2018, грудень, 11).

${ }^{2}$ Сприяння прозорості та впровадження антикорупційних заходів у державних підприємствах та органах місцевого самоврядування в Україні. Міжнародний цуентр перспективних досліджень.

$<$ http://icps.com.ua/nashi-proekty/aktualni-proekty-mtspd/spryyannya-prozorosti-ta-vprovadzhennya-

antykoruptsiynykh-zakhodiv-u-derzhavnykh-pidprymstvakh-ta-orhanakh-mistsevoho-samovryaduvannya-v-ukrayini/> (2020, липень, 03).

3 Див. напр. Польовий, М., Полухіна, А. (2020). Локальна демократія як важлива детермінанта муніципальної реформи в Україні: проблемні аспекти. Європейський політико-правовий дискурс, 7, 3, 128-133.

4 Див. напр.: «ПолітоLогічне»: затишний куточок для кожного закоханого у політологію сердечка. Фейсбук. $<$ https://www.facebook.com/politoLogich/> (2020, березень, 27);

Львівська асоціація політологів «Поліс». Фейсбук. <https://www.facebook.com/pg/lviv.polis> (2018, листопад, 02); Політологічне наукове товариство «Аналітик»: кафедра політології та державного управління ЧНУ імені Юрія Федьковича. Фейсбук. <https://www.facebook.com/analitykcv/> (2019, березень, 15).
} 
Ці заходи можливі з розширенням джерел фінансування науки та освіти, з цільовими державними програмами, з розвитком загальної культури комунікації в суспільстві. Такі, спрямовані на дію, прикладні політичні дослідження могли б об'єднати зусилля зацікавлених сторін, привабити молодих фахівців, сприяти науково обгрунтованим суспільно-політичним перетворенням. Перспективним вважаємо аналіз конкретних витрат та вигод від реалізації подібних проєктів, а також вивчення (не)матеріальних стимулів розвитку прикладної політології.

\section{References:}

1. The International Political Science Review: Most cited articles published in this journal in the last 3 years. SAGE Publishing. <https://journals.sagepub.com/action/showMostCitedArticles?journalCode=ipsa > (2020, July, 03). [in English].

2. Journal of Experimental Political Science: most cited articles in the last three years. Cambridge Core. $<$ https://www.cambridge.org/core/journals/journal-of-experimental-political-science/most-cited $>$ (2020, July, 03). [in English].

3. Vorotynskyi, I. Reinkarnatsiia radnyka, abo Navishcho Vydrin napysav knyhu dlia Putina [The Reincarnation of an Adviser, or Why Vydrin Wrote a Book for Putin]. Ukrinform. <https://www.ukrinform.ua/rubric-world/ 2860112-reinkarnacia-radnika-abo-naviso-vidrin-napisav-knigu-dla-putina.html $>$ (2020, January, 21). [in Ukrainian].

4. Reiestr naukovykh fakhovykh vydan Ukrainy [Register of scientific professional publications of Ukraine]. DNU "Ukrainskyi instytut naukovo-tekhnichnoi ekspertyzy ta informatsii" [Ukrainian Institute of Scientific and Technical Expertise and Information]. <http://resources.ukrintei.ua/refer/search $>$ (2020, July, 20). [in Ukrainian].

5. John, P. (2017). Field Experiments in Political Science and Public Policy. New York: Routledge, 222. $<$ doi: https://doi.org/10.4324/9781315773025>. [in English].

6. Ford, D.N. (2019). A system dynamics glossary. Syst. Dyn. Rev., Vol. 35: Issue 4, 369-379. $<$ doi:10.1002/sdr.1641>. [in English].

7. Fernández-Márquez, C.M., Vázquez, F.J., Medina, L.F. (2019). Imperfect Knowledge and Stable Governance in Democracies: An Agent-Based Model. Political Research Quarterly. <doi: https://doi.org/10.1177/1065912919834655>. [in English].

8. Rejting mediapopuljarnosti ukrainskih politicheskih jekspertov [Rating of media popularity of Ukrainian political experts]. Ukrainskij institut politiki [Ukrainian Institute of Politics]. <http://rating.uiamp.org.ua/politicheskieeksperty-i-kommentatory-v-smi-itogi-iyunya-0> (2020, July, 03). [in Russian].

9. Herasym, H. Yak shukaty komentatoriv politychnykh tem. [How to look for commentators on political topics]. MediaLab Online. <https://medialab.online/news/politology/> (2019, February, 12). [in Ukrainian].

10. Prykhovani piarnyky [Hidden PR people]. Teksty. [Texts]. <https://texty.org.ua/d/socio/\#people> (2020, July, 03). [in Ukrainian].

11. Donovan, C., Larkin, P. (2006). The Problem of Political Science and Practical Politics. Politics, 26(1), 11-17. <doi: https://doi.org/10.1111/j.1467-9256.2006.00246.x>. [in English].

12. Aiello, E., Donovan, C., Duque, E., Fabrizio, S., Flecha, R. Holm, P., Molina, S., Oliver, E, Reale, E. (2020). Effective strategies that enhance the social impact of social sciences and humanities research. Evidence \& Policy, vol xx, no xx, 1-16. <doi: https://doi.org/10.1332/174426420X15834126054137>. [in English].

13. McGann, J.G. 2019 Global Go To Think Tank Index Report. TTCSP Global Go To Think Tank Index Reports, 17. $<$ https://repository.upenn.edu/think_tanks/17/> (2020, January, 27). [in English].

14. Kruhlyi stil «Politychna osvita v Ukraini: suchasnyi stan i perspektyvy udoskonalennia» [Round table "Political education in Ukraine: current status and prospects for improvement"]. Tsentr Razumkova [Razumkov Center]. $<$ http://razumkov.org.ua/novyny/kruglyi-stil-politychna-osvita-v-ukraini-suchasnyi-stan-i-perspektyvyudoskonalennia> (2019, December, 18). [in Ukrainian].

15. Spryiannia prozorosti ta vprovadzhennia antykoruptsiinykh zakhodiv u derzhavnykh pidpryiemstvakh ta orhanakh mistsevoho samovriaduvannia $\mathrm{v}$ Ukraini [Promoting transparency and implementing anti-corruption measures in state-owned enterprises and local governments in Ukraine]. Mizhnarodnyi tsentr perspektyvnykh doslidzhen. [International Center for Policy Studies]. <http://icps.com.ua/nashi-proekty/aktualni-proekty-mtspd/spryyannyaprozorosti-ta-vprovadzhennya-antykoruptsiynykh-zakhodiv-u-derzhavnykh-pidprymstvakh-ta-orhanakhmistsevoho-samovryaduvannya-v-ukrayini/> (2020, July, 03). [in Ukrainian].

16. Polovyi, M., Polukhina, A. (2020). Lokalna demokratiia yak vazhlyva determinanta munitsypalnoi reformy v Ukraini: problemni aspekty [Local democracy as an important determinant of the municipal reform in ukraine: problem aspects]. Yevropeiskyi polityko-pravovyi dyskurs [European Political and Law Discourse], Vol. 7, Iss. 3, 128-133. [in Ukrainian].

17.Zvit pro rol rosiiskykh pryvatnykh armii u zbroinykh konfliktakh [The role of Russian PMCs in armed conflicts]. InformNapalm: International Volunteer Community. <https://informnapalm.rocks/pmc-rush-ua> (2018, December, 11). [in Ukrainian]. 
18. "PolitoLohichne": zatyshnyi kutochok dlia kozhnoho zakokhanoho u politolohiiu serdechka ["PolitoLogichne": a cozy corner for every heart in love with political science]. Facebook. <https://www.facebook.com/politoLogich/> (2020, March, 27). [in Ukrainian].

19. Lvivska asotsiatsiia politolohiv «Polis» [Lviv Association of Political Scientists "Polis"]. Facebook. $<$ https://www.facebook.com/pg/lviv.polis > (2018, November, 02). [in Ukrainian].

20. Politolohichne naukove tovarystvo «Analityk»: kafedra politolohii ta derzhavnoho upravlinnia ChNU imeni Yuriia Fedkovycha [Political Science Scientific Society "Analyst": Department of Political Science and Public Administration, Yuri Fedkovych Chernivtsi National University.]. Facebook. $<$ https://www.facebook.com/analitykcv/> (2019, March, 15). [in Ukrainian]. 